\title{
MONETARY POLICY SPILLOVERS THROUGH INDUSTRIAL GROWTH IN NIGERIA: A TIME SERIES ANALYSIS
}

\author{
Olatunji A. SHOBANDE \\ Business School, University of Aberdeen, Aberdeen, UK \\ Corresponding author's e-mail: o.shobande.19@abdn.ac.uk
}

\begin{abstract}
The study examines the impact of switching from direct to indirect monetary policy on industrial growth in Nigeria, using the annual time series data sourced from the Central Bank of Nigeria's (CBN) statistical bulletin between 1960 and 2015. The study adopts the Autoregressive Distributed Lag (ARDL) bound testing approach developed by Pesaran, Shin and Smith (2001) for estimating the relevant relationships. The result of the long-run estimates shows that domestic credit, interest rate and trade balance have positive impact on industrial output while money supply, inflation and exchange rate have negative impact on industrial growth. The result of the short-run dynamics shows that change in the previous (one and second lagged) periods of indirect monetary policy (interest rate, money supply, domestic credit and exchange rate) and industrial output were negatively related to change in industrial output. The error correction term indicates the speed of adjustment of equilibrium to their longrun position, which was found to be negative and significant. The study recommends that policy makers use both conventional and non-conventional monetary policies to speed up industrial output growth and enhance economic recovery by manipulating the macro-economic fundamentals.
\end{abstract}

Keywords: Growth, Industrial, Macroeconomics and Inflation, Monetary Policy.

JEL Classification: C32, E24, E52

\section{INTRODUCTION}

The techniques of monetary policy could be broadly divided into two groups: direct and indirect. The indirect approach is used extensively in more developed market economies, while the direct approach is predominant in the least developed economies of the third world, characterised by undeveloped money markets and centrally planned economies. Both techniques aim at influencing the cost and availability of banking system credit. The direct technique comprises the imposition of credit ceilings on individual banks, the regulation of deposits and lending rates, as well as sectorial credit allocation. The indirect technique achieves the same objectives through the use of Open Market Operations (OMO) supplemented with cash reserve requirements and discount window operations. Thus, indirect monetary policy actions are expected to be transmitted to the rest of the economy through the financial markets. The shift from direct to indirect monetary and credit control in Nigeria should therefore be seen as part of a broader government policy on deregulation of the Nigerian economy. 
In Nigeria, the objective of the monetary policy is anchored on the attainment of price stability, promoting industrial growth, correcting external exchange rate disequilibrium, as well as ensuring sustainable development. While efforts by the monetary authority to achieve this objective through money supply and interest rate manipulation has proved ineffective over time, the CBN since inception in 1958 has continued to use money supply to influence output growth tailored towards the long-term development. In 1958, the Apex Bank shifted from this approach to a guideline-directed approach aimed at enhancing sectorial performance of the economy. Between 1985 and 1986, the CBN continued to adopt a direct monetary policy framework to accommodate the Structural Adjustment Program (SAP) and to ensure the economy is stabilised enough to achieve industrial output growth. In 1993, there was a paradigm shift from direct to indirect monetary policy approach, due to the fact that the $\mathrm{CBN}$ decided to adopt $\mathrm{OMO}$ as a major instrument of monetary policy, with special emphasis on an interest rate tailored towards liquidity management. This approach was able to provide a new guideline on the operation of the monetary transmission mechanism. In 1996, the CBN shifted between fixing of an interest rate and partial deregulation to total deregulation using measures, such as abolition of credit allocation, adjustment of cash ratio to cover all deposit liabilities, and introduction of prudential guideline (Kure, Bewaji, and Ochu, 2012 and Adeoye and Shobande, 2016). Between 2000 and 2002, the CBN decided to adopt a medium-term monetary framework, realizing that a long-term monetary policy focus was not easy to achieve. Thus, the monetary policy approach was based on minimizing time inconsistency problem and setting conditions for bank periodical adjustment of its target.

Between 2006 and 2011, the CBN implemented policies designed to replace the Minimum Discount Rate (MRR) with the Monetary Policy Rate (MPR), and a standing facility window with upper and lower corridor for the standing, lending and deposit facility, using complementary measures, such as cash reserve requirement, liquidity ratio, foreign exchange swap, among others. This approach was a continuous practice from 2012 to 2016. Based on the peculiarity of the structure of the Nigerian economy (where the productivity level of the real sector is influenced by the traditional agricultural and industrial economy that appears to be low), reducing the monetary policy rate may not add to a positive influence as expected. Hence, the use of the monetary policy rate to influence industrial growth may be a question of empirical investigation. It appears that there is a widened gap between the prime and maximum lending rate, which implies that a higher premium is placed on prime lenders, to which a majority of new emerging industrial investors who could accelerate the growth of the economy belongs (Adeleke, Uboh, and Shobande, 2016).

While economic literature has clearly demonstrated that Small and Medium Scale Enterprises (SMEs) have potential to speed up the industrial process and rescue the country through large production at lower economy of scale, the question on the extent to which the current monetary policy could assist these firms through mobilization, disbursement and effective allocation of funds becomes the bone of contention in this paper. On a second note, the existing relationship between the monetary policy and the exchange rate is also a potential interest in this paper. In 
addition, the critical question, which this study intends to investigate is to what extent can the CBN control monetary base to enhance industrial output? Does the direct or indirect monetary policy anchored on the interest rate impact the industrial sector? Can the monetary policy and the exchange rate guarantee an increase in industrial output? Is macroeconomic uncertainty through inflationary targeting necessary for the industrialization process? The answers to these questions are expected to provide a possible outcome for a quick growth plan and easy economic recovery in Nigeria.

The rest of this paper is divided into five sections. Section 2 provides a summary of the theoretical framework and literature review. This is followed by the analytical framework and methodological approaches articulated in Section 3, while the main results of the study are presented in Section 4. Section 5 concludes the study with a summary of the main results and policy recommendations.

\section{LITERATURE REVIEW}

Theoretically, there are two strong literature sources that attempt to explain the relationship between monetary policy and industrial growth. First, it is the oldest interest rate transmission channel postulated by Keynes in 1936. In Keynes's suggestion, monetary policy can act as a catalyst for industrial growth, through the short-term interest rates, such as overnight, one week and one-month rate, which exert a positive or negative influence on the industrial output level. Keynes further demonstrated his hypothesis, using the liquidity preference theory, where the nominal interest rate is a function of demand for and supply of money (Shobande $\&$ Oke, 2016). Keynes further explained that an increase in money supply will trigger an increase in price, which in turn exerts force on inflationary expectation, leading to a decrease in the interest rate and an increase in aggregate demand, and speeds up the rate of industrial output level.

The second monetary policy transmission mechanism that can accelerate or influence industrial output is the credit monetary policy transmission mechanism. This approach suggests that the Apex Bank can act as a catalyst for speeding up industrial growth, by moral persuasion or credit guideline, in which the deposit money bank is expected to mobilize and disburse funds to SMEs and emerging industrial investors with the hope of influencing aggregate demand and increasing output (Shobande \& Oke, 2016).

In terms of empirical investigations, various studies have attempted to empirically establish the relationship between monetary policy and economic growth. Some of these studies are country-specific while others are cross-country studies. In terms of the output of their studies, some documented a positive relationship among the variables considered and their choice of environments; others found a negative relationship while relatively few studies had a mixed review. Some studies such as Ajisafe and Folorunso (2002), Khabo (2002), Bhuiyan (2008), Chukwu (2009) Omoke and Ugwuanyi (2010), Nouri and Samimi (2011), Akujobi (2012), Umaru and Zubairu, (2012), Onyeiwu (2012), Bernhard (2013), Fasanya, Onakoya and Agboluaje (2013), Owalabi and Adegbite (2014), Micheal 
and Ebibai (2014), Anwor and Okorie (2016) documented that the monetary policy positively or significantly affects economic growth.

Ajisafe and Folorunso (2002) employed the co-integration and error correction model on time series data from 1970 until 1998 to study the relative effectiveness of monetary and fiscal policy on economic activity in Nigeria. The study documented that the monetary policy exerted a greater impact on an economic activity than the fiscal policy in Nigeria. The authors concluded that governmental emphasis on fiscal policy actions led to a greater distortion in the Nigerian economy. In South Africa, Khabo (2002) examined the effect of monetary policy on a small and open economy, using the Ordinary Least Square (OLS) method and data from 1960 and 1997. Using M3 to measure the monetary policy, the study revealed that economic growth significantly influenced money supply. In Canada, Bhuiyan (2008) investigated the effect of monetary policy shocks, using monthly data from 1994 to 2007, and the overnight target rate as an instrument of monetary policy. The study revealed that the transmission of monetary policy shocks to real output operated through the interest rate and exchange rate.

Chukwu (2009), using the Structural Vector Auto-Regression (SVAR) approach, examined the effect of monetary policy innovations in Nigeria. The study analysed broad money (M2), Minimum Rediscount Rate (MRR) and Real Effective Exchange Rate (REER) as alternative policy instruments to trace the effects of monetary policy shocks on output and prices in Nigeria. It was revealed that monetary policy innovations exerted a real and nominal effect on economic parameters, depending on the policy variable selected.

Omoke and Ugwuanyi (2010) examined the relationship between inflation and output in Nigeria, employing the co-integration econometric technique and Granger causality test. The study revealed non-existence of co-integrating vector in the series used, which led to the documentation that monetary stability could lead to price stability in the Nigerian economy, mainly because a change in price level was caused by a change in money supply. The study also arrived at the conclusion that in Nigeria inflation, to a large extent, was a monetary phenomenon.

In Iran, Nouri and Samimi (2011) studied the impact of monetary policy on economic growth, employing the ordinary least square methodology and data from 1974 to 2008 . Using money supply as a measure of monetary policy, they found that money supply was positively and significantly related to economic growth. Akujobi (2012) made use of multiple regression analysis to examine the effect of monetary policy instrument on economic development in Nigeria. The study revealed that treasury bill, MMR and liquidity rate significantly influenced economic development in Nigeria. Umaru and Zubairu (2012) explored the impact of inflation on economic growth and development in Nigeria, using the augmented Dickey-Fuller technique and Granger causality approach based on data collected from 1970 and 2010. The study revealed that Gross Domestic Product (GDP) caused inflation, and further documented that inflation positively affected economic growth. Thus, the rate of inflation in the Nigerian economy is vital for a good performance of the economy in terms of per capita growth.

In Nigeria, Onyeiwu (2012) empirically studied the effect of monetary policy on the Nigerian economy, with the aid of the Ordinary Least Square (OLS) method 
and money supply as a measure of monetary policy. The study revealed that monetary policy had positively affected the growth of GDP, as well as balance of payment. The study also documented that money supply had a negative effect on the rate of inflation and concluded that $\mathrm{CBN}$ monetary policy was effective in the Nigerian economy via the regulation of liquidity in the economy. Bernhard (2013) investigated the relationship between channels of monetary transmission and selected macroeconomic aggregates in Nigeria. The study revealed that interest rate, exchange rate and credit channels were functional for inflation targeting. The study of Onyeiwu (2012) was consistent with that of Fasanya, Onakoya and Agboluaje (2013), which employed the Error Correction Model (ECM) and time series data from 1975 to 2010 in order to investigate the impact of monetary policy on economic growth. The findings indicated that there was a long-run relationship between monetary policy and economic growth, and that inflation rate, exchange rate and external reserve ratio were significant monetary policy instruments fostering economic growth in Nigeria.

Owalabi and Adegbite (2014) analysed the effect of monetary policy on industrial growth in Nigeria, with the use of multiple regression analysis. The study showed that manufacturing output, treasury bills, deposit and lending, and rediscount rate significantly affected industrial growth. Michael and Ebibai (2014) in their study of the Nigerian economy, investigated the impact of monetary policy on macro-economic variables (GDP, inflation and balance of payment) using the OLS regression technique. According to the outcome of the study, increasing the growth rate of GDP in Nigeria will require the provision of an investment-friendly environment. Anwor and Okorie (2016) examined the impact of monetary policy on economic growth, using time series data from 1982 to 2013, and the error correction model approach. Their study revealed that the monetary policy positively affected sustained economic growth and price stability, owing to the fact that a unit increase in Cash Reserve Ratio (CRR) would lead to approximately seven units increase in economic growth in Nigeria.

Studies by Dele (2007), Berument and Dincer (2008), Olorunfemi and Dotun (2008) documented a negative relationship between monetary policy and economic growth. Dele (2007) made use of the Generalized Least Square (GLS) method in the study of West African Monetary Zone Countries (Gambia, Ghana, Guinea, Nigeria and Sierra Leone) to examine the relationship between the monetary policy and economic performance. He made use of data between 1991 and 2004 employing such variables as money supply (M2), MRR, banking system credit to private sector, banking system credit to central government and exchange rate of the national currency to the US dollar as a measure of monetary policy. The study revealed that monetary policy was a source of stagnation to economic performance because it negatively affected the real domestic output of these countries. In Turkey, Berument and Dincer (2008) examined the effect of monetary policy using the Structural Vector Auto-regression (SVAR) approach and data from 1986 to 2000. The study revealed that a tight monetary policy had temporarily effects on output, with evidence of a decline in output for three months in a statistically significant fashion. 
Olorunfemi and Dotun (2008) made use of a simple regression analysis in order to study the effect of monetary policy on economic performance in Nigeria. The study revealed a negative relationship between the interest rate and GDP, inflation and GDP. However, the authors did not disaggregate the impact of monetary policy on a sectorial basis. Okwo et al. (2012) analysed the effect of monetary policy outcomes on macroeconomic stability in Nigeria, using such variables as credit-toprivate sector, net credit-to-government, and inflation as a measure of monetary policy. The results presented by the OLS methodology revealed that none of the variables were significant. This result was attributed to the fact that the monetary policy might have been inactive in the stimulation of price stability. Adeoye and Saibu (2014) employed the use of changes in various monetary policy instruments to examine the effects of monetary policy shocks on exchange rate volatility in Nigeria with the outcome that both real and nominal exchange rates had an unstable relationship. Udude (2014) in her study on the impact of monetary policy on economic growth in Nigeria used time series data from 1981 to 2012, Johansen's co-integration techniques, as well as the Vector Error Correction model (VECM). Her study revealed that monetary policy did not affect significantly economic growth in Nigeria during the review period. She attributed this limited contribution to growth on shortcomings from monetary policy instruments and recommended a strict adherence of commercial banks and other financial intermediaries to CBN guidelines.

Studies by Starr (2005), Uhlig (2004), Rafiq and Mallick (2008) were inconclusive, as they could not provide enough evidence as to whether the monetary policy positively or negatively affected economic growth. In the study of four core CIS countries (Russia, Ukraine, Kazakhstan, and Belarus), Starr (2005) examined the relationship between monetary policy variables, output and prices in the poststabilization period, using the Granger causality approach. The study used quarterly data ranging between 1995 and 2003 and revealed that there was not enough evidence as to the real effect of monetary policy in the four CIS countries, though the interest rate had a significant impact on the output in Russia. The result of this study was consistent with that of Uhlig (2005) who demonstrated that contractionary monetary policy shocks had no clear effect on real GDP in the USA. In the study of three large euro area economies (Germany, France, and Italy), Rafiq and Mallick (2008) made use of quarterly data from 1981 to 2005 and the new VAR identification procedure to analyse the effect of monetary policy on the output. The study revealed that apart from Germany, it was ambiguous as to whether a rise in the interest rate would lead to a fall in output, thereby displaying a lack of homogeneity in the responses.

Some studies such as Adefeso and Mobolaji (2010), Okoro (2013), Chipote Precious and Makhetha-Kosi Palesa (2014) established a long-run relationship between the monetary policy and economic growth. Adefeso and Mobolaji (2010) employed the Johansen Maximum Likelihood Co-integration procedure to examine the relationship between fiscal-monetary policy and economic growth in Nigeria. Their study revealed that there is a long-run relationship between economic growth, degree of openness, broad money supply (M2) and government expenditure. 
By testing the influence of interest rate, inflation, exchange rate, money supply and credit on GDP, Okoro (2013) investigated the effect of monetary policy on economic growth in Nigeria, using Johansen's co-integration test and error correction. He noted there was a long-run equilibrium relationship between the monetary policy and economic growth and the entire variable considered in the model. In South Africa, Chipote and Makhetha-Kosi (2014) examined the impact of monetary policy on economic growth, using Johansen's co-integration test and error correction mechanism over a 10-year period, between2000 and 2010. Their study revealed that there was a long-run relationship between monetary policy variables and economic growth, with inflation being significant, while money supply, repo rate and exchange rate were insignificant.

\section{METHODOLOGY}

\subsection{Modelling Monetary Policy Framework for Industrial Growth}

The study takes into consideration a simple monetary model to explain the interaction of monetary policy with industrial growth. The consideration of monetary policy was in two markets at period $t$ : good for money at price $P_{t}$ and labour for money at the nominal wage $W_{t}$. There are two types of representative agents: firms and households. The firms have a technology:

$$
Y_{t}=A_{t} L_{t}^{1-\alpha}
$$

Where $L_{t}$ is labour input and $A_{t}$ is a stochastic technological shock. In period $t$, the representative household works $L_{t}$, consumes $C_{t}$, and ends the period with a quantity of money $M_{t}$. It maximizes the expected value of discounted future with the following utility of the money in the utility function expressed and not excluding the real money balances $M_{t} / P_{t}$ :

$$
U=\sum_{t=0}^{\infty} \beta^{t}\left[\log C_{t}+w \log \left(M_{t} / P_{t}\right)-r\left(L_{t}\right)\right],
$$

where $r$ is an increasing function representing the disutility of labour. At the beginning of time $t$, there is a stochastic multiplication monetary shock denoted as $X_{t}$ : money holdings $M_{t-1}$ carried from the previous period are multiplied as $X_{t} M_{t-1}$. Therefore, the budget constraint for the period becomes:

$$
P_{t} C_{t}+M_{t}=W_{t} L_{t}+\pi_{t}+X_{t} M_{t-1},
$$

where $\pi_{t}$ is distributed profit of the industrial sector.

Taking Walrasian seriously and not forgetting that in period $t$ firms demand labour competitively, the real wage is equal to the marginal productivity of labour:

$$
W_{t} /_{P_{t}}=\partial Y_{t} / \partial L_{t}=(1-\alpha) Y_{t} /_{L_{t}}
$$

The representative households maximize the expected value of their discounted utility in the budget constraints forming a Lagrangian function as follows: 


$$
\begin{aligned}
& \sum_{t=0}^{\infty} \beta^{t}\left[\log C_{t}+w \log \left(M_{t} / P_{t}\right)-r\left(L_{t}\right)+\gamma_{t}\left(W_{t} / P_{t} L_{t}+X_{t} M_{t-1} / P_{t}-C_{t}-\right.\right. \\
& \left.\left.M_{t} / P_{t}\right)\right]
\end{aligned}
$$

The first order condition for the customer yield:

$$
\begin{gathered}
\frac{1}{C_{t}}=\gamma_{t} \\
\left(L_{t}\right)=\gamma_{t}{ }^{W} / P_{t} \\
\gamma_{t}=w P_{t} /_{M_{t}}+\beta E_{t}\left(\gamma_{t+1} X_{t} P_{t+1} / P_{t+1}\right)
\end{gathered}
$$

The equilibrium condition for the money is that the quantity of money $M_{t}$ demanded by household be equal to the initial money holding $X_{t} M_{t-1}$ :

$$
M_{t}=X_{t} M_{t-1}
$$

Using the condition in Equations (6) and (8):

$$
M_{t} P_{t} C_{t}=w+\beta E_{t}\left(M_{t+1} / P_{t+1} C_{t+1}\right)
$$

This leads to:

$$
M_{t} / P_{t} C_{t}={ }^{w} / 1-\beta Y_{t}
$$

From Equation (11), we have established that the economy is continuously subject to monetary shocks, fluctuations in real industrial output growth and is driven by real economic variables responsible for these shocks. The lack of effect of this monetary shock is due to specific money creation process embedded in the Interswitch between direct and indirect monetary policy transmission mechanism (see Benassy, 2011).

\subsection{Model Specification and Data Source}

This study investigates the impact of monetary policy transmission on the industrial output growth in Nigeria. Several scholars have identified the contemporary relationship between monetary policy variables and industrial output growth, but this study proposes re-establishing if the relationship still exists.

Drawing from Starr's (2005), Uhlig's (2004), Rafiq and Mallick's (2008) model on the monetary transmission mechanism and economic growth, which was adapted by Michael and Ebibai (2014), our model is specified as follows:

$$
G D P_{t}=\beta_{0}+\beta_{1} M S_{t}+\beta_{2} D C_{t}+\beta_{3} I N T_{t}+\beta_{4} E X R_{t}+\beta_{5} I N F_{t}+\beta_{6} T B_{t}+\mu_{t}
$$

Where: $G D P$ is gross domestic product; $M S$ is money supply; $D C$ is domestic credit; TB is trade balance; EXR is exchange rate; INF is inflation rate; INT is interest rate; $\beta_{0}$ is constant, $\beta_{1-6}$ are slopes, $\mu$ is error term; and $t$ is time.

The theoretical expectation of the model expects the slope of money supply to be positive. An increase in money supply will bring about an increase in the total 
money in circulation in the country. Invariably, it will increase aggregate demand and lead to a rise in productive activities and investment opportunities in the economy. This rise in the productive activities in the economy will lead to a rise in output, thus leading to economic growth in the country. Similarly, a direct relationship between trade balance and economic growth is expected because balance of trade is favourable, i.e., when export is greater than import, there is favourable trade surplus, which will invariably translate to growth. However, domestic credit is expected to have a positive relationship with output growth. An increase in exchange rate (price of a country's currency with respect to other currencies of the world) will make the domestic currency cheaper in the foreign exchange market. This depreciation in the domestic currency will make exports cheaper and imports expensive in the international market for goods and services. As a result, our goods and services would be more in demand, thus leading to a rise in the output of the country. Interest rate and inflation are expected to have a negative relationship with output growth in the economy.

The data used, which are mainly secondary, are sourced from the CBN statistical bulletin 2015, volume 26 and the National Bureau of Statistics (NBS). The period considered lies between 1960 and 2015.

\subsection{ARDL Bounds Cointegration Test}

The study employs the Autoregressive Distributed Lag (ARDL) bounds test by Pesaran, Shin and Smith (2001) to examine the effects of monetary policy on output growth in the long- and short-run periods in Nigeria. Using this approach, output growth is expressed as a function of the lagged value of itself and the current and the lagged values of the explanatory variables.

$$
\begin{gathered}
\Delta g d p_{t}=a_{0}+\sum_{p=1}^{n} b_{p} \Delta g d p_{t-p}+\sum_{p=1}^{n} c_{p} \Delta m s_{t-p}+\sum_{p=1}^{n} d_{p} \Delta d c_{t-p}+ \\
\sum_{p=1}^{n} e_{p} \Delta t b_{t-p}+\sum_{p=1}^{n} f_{p} \Delta \operatorname{exr}_{t-p}+\sum_{p=1}^{n} g_{p} \Delta \inf _{t-p}+\sum_{p=1}^{n} h_{p} \Delta i n t_{t-p}+\rho_{1} g d p_{t}+ \\
\rho_{2} m s_{t}+\rho_{3} d c_{t}+\rho_{4} t b_{t}+\rho_{5} \operatorname{exr}_{t}+\rho_{6} \text { inf }_{t}+\rho_{7} \text { int }_{t}+\varepsilon_{t}
\end{gathered}
$$

Where $\Delta$ is the first difference operator. The parameter $\rho_{i}$, where $i=1,2,3,4,5,6,7$ is the respective long-run multiplier, while the parameters $b, c$, $d, e, f, g, h$ are the short-run dynamic coefficients of the underlying ARDL model in the equation. $\varepsilon_{t}$ denotes the white noise error term. The bounds cointegration test will involve estimating Equation (13) and restricting the parameters of the lag level variables to zero. Based on this equation, we tested the following null and alternative hypotheses:

$$
H_{0}=\rho_{1}=\rho_{2}=\rho_{3}=\rho_{4}=\rho_{5}=\rho_{6}=\rho_{7}=0
$$

(i.e., no cointegration or level relationship) as against

$$
H_{1}=\rho_{1}=\rho_{2}=\rho_{3}=\rho_{4}=\rho_{5}=\rho_{6}=\rho_{7} \neq 0 .
$$

The existence of a co-integrating relationship among the variables is determined by testing the significance of the lag levels of the variables using the Ftest. The calculated F-statistic is compared with the two critical values for the upper and lower bounds tabulated by Narayan (2004). Owing to the fact that the direction 
of cointegration is not a priori established, each variable is normalized as a dependent variable, while the existence of level relationship is tested. The study has also conducted diagnostic tests such as serial correlation, normality, functional form and heteroscedasticity tests.

\section{ECONOMETRIC ANALYSIS}

\subsection{Descriptive Analysis}

Table 1 presents the descriptive analysis of the time series properties of the variables included in the model. The descriptive statistics was carried out between money policy instruments and economic growth in Nigeria from 1960 to 2015. Table 1 shows that the mean value of money supply $(M S)$, domestic credit $(D C)$, interest rate $(I N T)$, exchange rate $(E X R)$, inflation rate $(I N F)$, trade balance $(T B)$ and gross domestic product $(G D P)$ stood at $10.9 \%, 10.4 \%, 9.97 \%, 1.87 \%$, $15.57 \%, 6.85 \%$ and $11.55 \%$, respectively. The standard deviation of money supply $(M S)$, domestic credit $(D C)$, interest rate $(I N T)$, exchange rate $(E X R)$, inflation rate $(I N F)$, trade balance $(T B)$ and gross domestic product $(G D P)$ from their respective long-term mean values every year point at $3.65 \%, 3.82 \%, 5.11 \%$, $2.34 \%, 16.75 \%, 8.05 \%$ and $2.56 \%$. The probability value of Jarque-Bera statistics for all variables shows their distribution level at mean zero and constant variance. It indicated that interest rate, money supply, domestic credit and gross domestic product were normally distributed among all the variables of interest.

Table 1. Descriptive Statistics

\begin{tabular}{|l|c|c|c|c|c|c|c|}
\hline & $\boldsymbol{G D P}$ & $\boldsymbol{M S}$ & $\boldsymbol{D C}$ & $\boldsymbol{I N T}$ & $\boldsymbol{E X R}$ & $\boldsymbol{I N F}$ & $\boldsymbol{T B}$ \\
\hline Mean & 11.5485 & 10.8495 & 10.3893 & 9.9688 & 1.8693 & 15.4779 & 6.8505 \\
\hline Maximum & 18.0500 & 16.7547 & 16.7427 & 26.000 & 5.2806 & 72.8100 & 15.5773 \\
\hline Minimum & 7.8196 & 5.5895 & 4.6944 & 3.5000 & -0.6045 & 0.2900 & -14.6179 \\
\hline Std. Dev. & 2.5627 & 3.6516 & 3.8278 & 5.1055 & 2.3380 & 16.7539 & 8.0456 \\
\hline Skewness & 0.3090 & 0.1055 & 0.1367 & 0.6596 & 0.2717 & 1.7527 & -0.9506 \\
\hline Kurtosis & 3.2172 & 1.7225 & 1.7653 & 3.0476 & 1.3359 & 5.3805 & 2.8627 \\
\hline Jarque-Bera & 1.0012 & 3.9121 & 3.7319 & 4.0662 & 7.1508 & 41.895 & 8.4772 \\
\hline Probability & 0.6062 & 0.1414 & 0.1548 & 0.1309 & 0.0280 & 0.0000 & 0.0144 \\
\hline Obs. & 56 & 56 & 56 & 56 & 56 & 56 & 56 \\
\hline
\end{tabular}

Source: The author's computation (2017). 


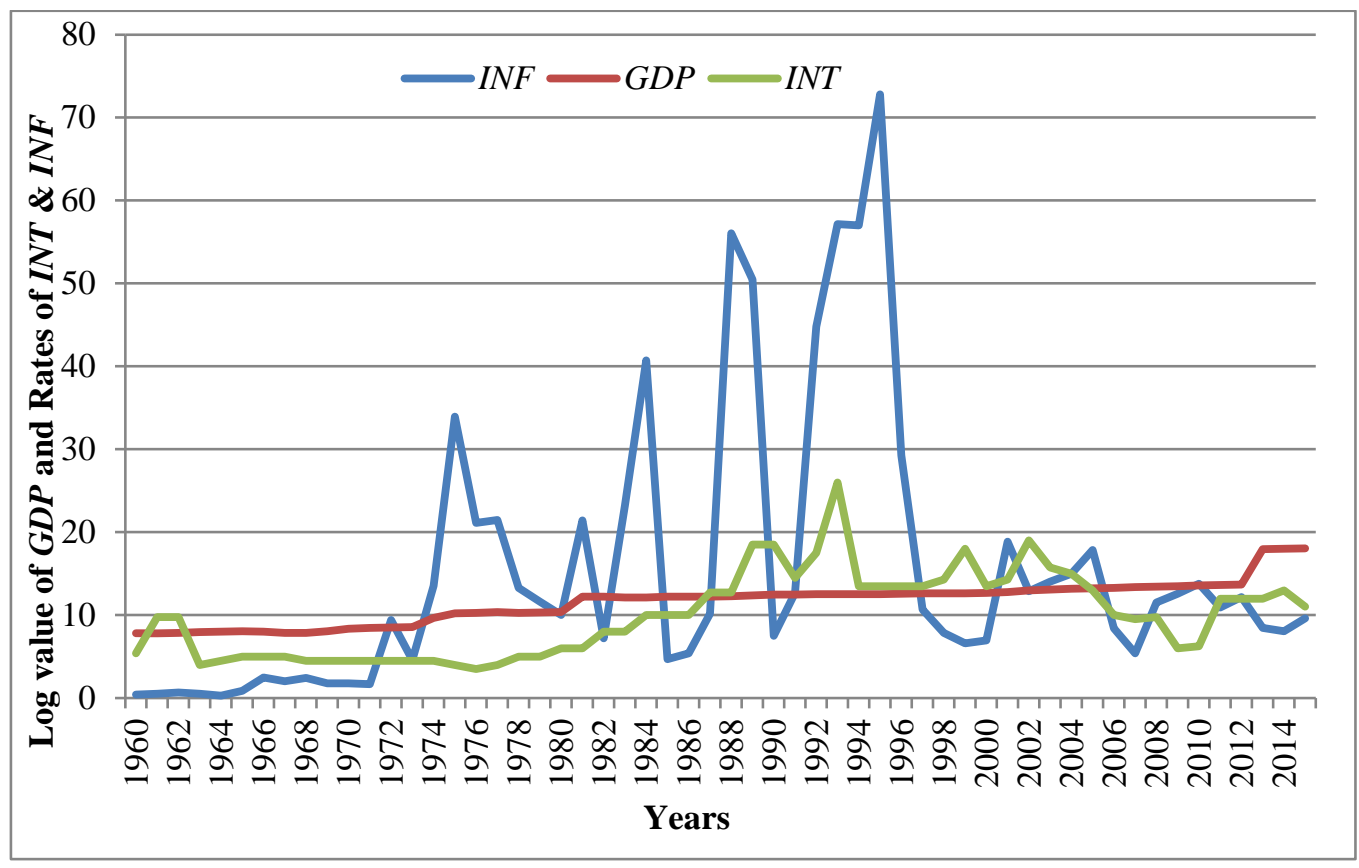

Fig. 1. Interest rate, inflation rate and GDP.

Figures 1 and 2 illustrate the relationship among monetary policy instruments and output growth in Nigeria during the period 1960 to 2015. The relationship between the variables is not clear enough to indicate whether it is positive or negative. To some extent, there is similar movement between money supply and domestic credit throughout the periods. The growth rate of output fluctuates between $7.81 \%$ and $18.05 \%$. The growth in interest rate changes from the inception till 2015, likewise the inflation rate.

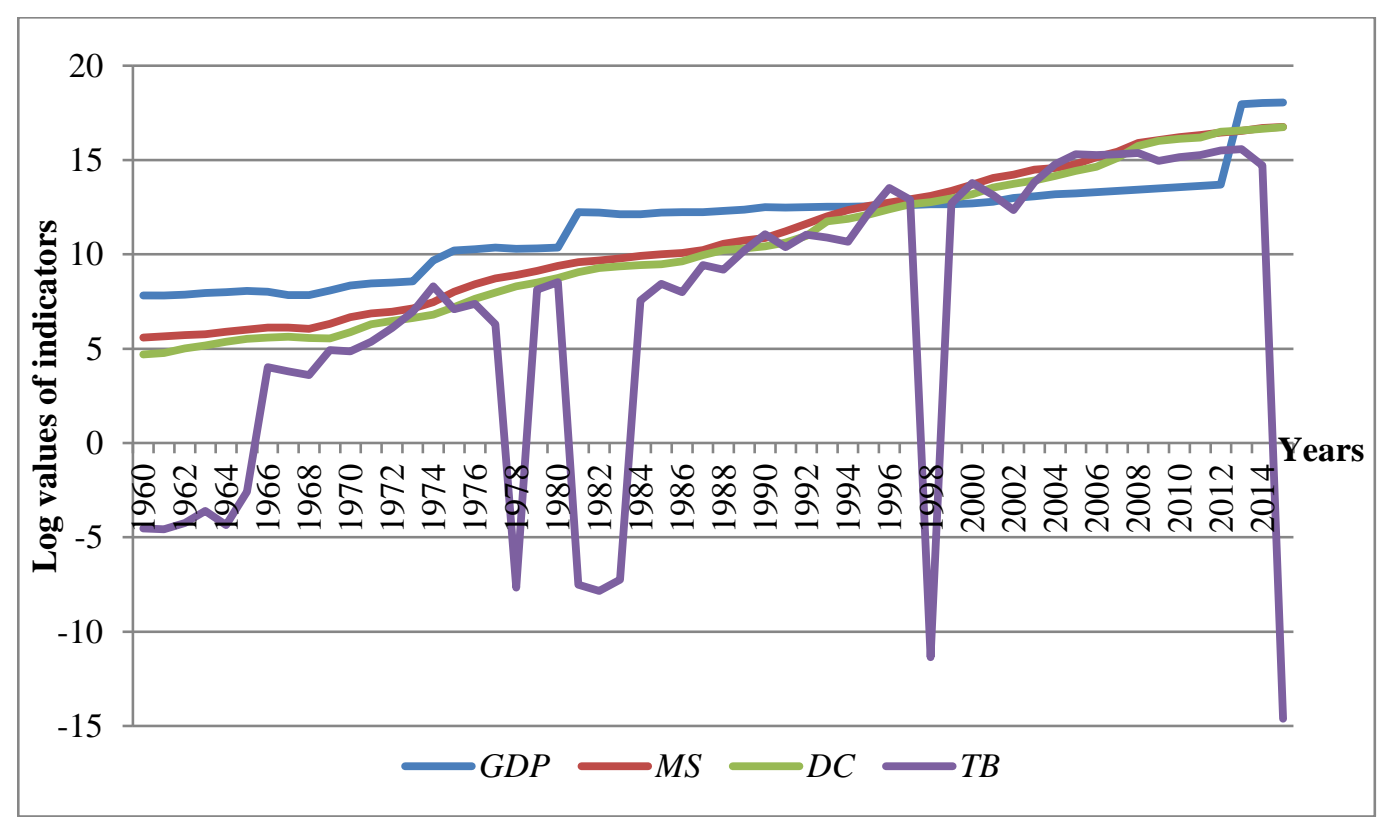

Fig. 2. Domestic credit, money supply, trade balance and GDP. 
Thus, the inconclusiveness of the direction of our variables necessitates the need for an empirical analysis.

Table 2. ADF Unit Root Test Results

\begin{tabular}{|c|c|c|c|}
\hline \multirow{2}{*}{ Variables } & \multicolumn{2}{|c|}{ ADF Tau Statistics } & \multirow{2}{*}{$\begin{array}{c}\text { Order of } \\
\text { Integration }\end{array}$} \\
\cline { 2 - 3 } & Intercept & Linear Trend & \\
\hline $\boldsymbol{I N T}$ & $-8.2630(1)[-3.5600]^{*}$ & $-8.1803(1)[-4.1409]^{*}$ & 1 \\
\hline $\boldsymbol{M S}$ & $-3.8149(0)[-3.5575]^{*}$ & $-3.7344(0)[-4.1373]^{*}$ & 1 \\
\hline $\boldsymbol{D C}$ & $-5.0183(0)[-3.5575]^{*}$ & $-4.9720(0)[-4.1373]^{*}$ & 1 \\
\hline $\boldsymbol{T B}$ & $-3.5553(0)[-3.5550]^{*}$ & $-4.0508(0)[-3.4937]^{*}$ & 0 \\
\hline $\boldsymbol{E X} \boldsymbol{R}$ & $-5.7924(0)[-3.5575]^{*}$ & $-5.8375(0)[-4.1373]^{*}$ & 1 \\
\hline $\boldsymbol{I N F}$ & $-3.4829(0)[-3.5550]^{* *}$ & $-3.4694(0)[-3.4937]^{* *}$ & 0 \\
\hline $\boldsymbol{G D P}$ & $-7.3547(0)[-3.5575]^{*}$ & $-7.4264(0)[-4.1373]^{*}$ & 1 \\
\hline
\end{tabular}

Note: * significant at $1 \%$;* significant at $5 \%$; *** significant at $10 \%$. MacKinnon critical values are shown in parenthesis. The lagged numbers shown in brackets are selected using the minimum Schwarz and Akaike information criteria.

Source: The author's computation (2017).

\subsection{Unit Root Test Results}

Table 2 presents the results of the time series properties of the variables included in the model. This pre-test was carried out before estimating the long-run and short-run relationship among monetary policy instruments and economic growth in Nigeria (1960-2015).

The Augmented Dickey Fuller (ADF) unit root test results, which are presented in Table 4. that trade balance $(T B)$ and inflation rate $(I N F)$ are stationary at levels [I(0)]. However, interest rate (INT), money supply $(M S)$, domestic credit $(D C)$, exchange rate $(E X R)$ and gross domestic product $(G D P)$ were reported to be stationary at first difference $[\mathrm{I}(1)]$. Thus, these series are non-mean reverting at levels and do not converge to their long-run equilibrium until they are first differenced.

\subsection{Autoregressive Distributed Lag (ARDL) Results}

\subsubsection{ARDL Cointegration Result}

Econometric literature argues that regressing a stationary series on nonstationary series has severe implications in drawing policy inference. The data series provides evidence for the use of Autoregressive Distributed Lag (ARDL) technique of analysis. As posited by Pesaran et al. (2001), ARDL is more suitable for variables at different order of integration. The F-statistics estimates for testing the existence of long-run relationship between monetary policy instruments and economic growth in Nigeria are presented below: 
Table 3. Existence of Long-Run Relationship between Monetary Policy and Output Growth

\begin{tabular}{|l|c|c|}
\hline Test Statistic & Value & $\boldsymbol{k}$ \\
\hline F-statistics $(G D P \mid M S, D C, I N T, I N F, E X R, T B)$ & 4.3531 & 6 \\
\hline Critical Value Bounds & I0 Bound & I1 Bound \\
\hline Significance & 2.12 & 3.23 \\
\hline $10 \%$ & 2.45 & 3.61 \\
\hline $5 \%$ & 2.75 & 3.99 \\
\hline $2.5 \%$ & 3.15 & 4.43 \\
\hline $1 \%$ & & \\
\hline
\end{tabular}

Source: The author's computation (2017).

The estimated F-statistics of the normalized equations $\left(\mathrm{F}_{\mathrm{arb}}=4.3531\right)$ is greater than the lower and upper critical bound at $5 \%$ significance level as in Table 3. It implies that the null hypothesis of no long-run relationship is rejected at $5 \%$ significance level. The implication of the above estimation is that money supply $(M S)$, domestic credit $(D C)$, interest rate $(I N T)$, exchange rate $(E X R)$, inflation rate $(I N F)$, trade balance $(T B)$ and gross domestic product $(G D P)$, all have an equilibrium condition that keeps them together in the long run.

\subsubsection{Results of Long-run Estimates of Monetary Policy Instruments and Output Growth Using the ARDL Approach}

Table 4 reveals the long-run estimates between monetary policy instruments and output growth in Nigeria.

Table 4. Long-run Coefficients [ARDL: 3, 1, 3, 4, 0, 0, 0]

\begin{tabular}{|c|c|c|c|c|}
\hline Dependent Variable: Output growth $(G D P)$ & Prob. \\
\hline Variables & Coefficients & Std. Error & t-Statistic & 0.1686 \\
\hline$M S$ & -1.451727 & 1.032124 & -1.406542 & 0.0234 \\
\hline$D C$ & 2.410645 & 1.015304 & 2.374308 & 0.0082 \\
\hline$I N T$ & 0.128872 & 0.045878 & 2.809023 & 0.8856 \\
\hline$I N F$ & -0.130600 & 0.901100 & -0.144920 & 0.0000 \\
\hline$E X R$ & -0.853891 & 0.178367 & -4.787282 & 0.9929 \\
\hline$T B$ & 0.016800 & 1.870300 & 0.008998 & 0.0079 \\
\hline$C$ & 2.815504 & 0.996959 & 2.824091 & \\
\hline
\end{tabular}

Source: The author's computation (2017).

The long-run estimates suggested that domestic credit (DC), interest rate (INT), and trade balance $(T B)$ had a positive impact on output growth $(G D P)$ in Nigeria and all these conformed to theoretical expectation, except the interest rate. Specifically, a $1 \%$-point increase in domestic credit $(D C)$, interest rate (INT), and 
trade balance $(T B)$ increased output growth $(G D P)$ by $2.41 \%, 0.13 \%$ and $0.02 \%$, respectively.

However, Table 4 reveals that money supply $(M S)$, inflation rate $(I N F)$ and exchange rate $(E X R)$ had a negative impact on output growth $(G D P)$ in Nigeria. This conforms a priori expectation, except money supply and exchange rate. Thus, if money supply $(M S)$, inflation rate $(I N F)$ and exchange rate $(E X R)$ increase by $1 \%$, output growth $(G D P)$ deteriorates by $1.45 \%, 0.13 \%$ and $0.85 \%$, respectively. Table 4 shows that domestic credit, interest rate and exchange rate were statistically significant respectively at 0.05 critical values.

\subsubsection{Error Correction Models Using the ARDL Approach}

The short-run dynamic relationship between monetary policy instruments and output growth in Nigeria indicating the second part of the estimated ARDL model is reported below in Table 5. The lag lengths were selected based on Akaike Information Criterion (AIC). The table below reveals the short-run dynamic estimates among variables of interest.

Table 5. Estimated Short-run Error Correction Model [ARDL: 3,1,3,4,0,0,0]

\begin{tabular}{|c|c|c|c|c|}
\hline Dependent Variable: Output growth $(G D P)$ \\
\hline Variables & Coefficient & Std. Error & t-Statistic & Prob. \\
\hline$\Delta(\boldsymbol{G D P}(-\mathbf{1}))$ & 0.406186 & 0.201656 & 2.014255 & 0.0519 \\
\hline$\Delta(\boldsymbol{G D P}(-\mathbf{2}))$ & 0.429811 & 0.240462 & 1.787440 & 0.0828 \\
\hline$\Delta(\boldsymbol{M S})$ & 0.783059 & 0.924160 & 0.847320 & 0.4027 \\
\hline$\Delta(\boldsymbol{D C})$ & -0.071567 & 0.975959 & -0.073330 & 0.9420 \\
\hline$\Delta(\boldsymbol{D C}(-\mathbf{1}))$ & 3.302173 & 1.130268 & 2.921584 & 0.0061 \\
\hline$\Delta(\boldsymbol{D C}(-\mathbf{2}))$ & -2.344758 & 0.671965 & -3.489403 & 0.0014 \\
\hline$\Delta(\boldsymbol{I N T})$ & 0.082050 & 0.039677 & 2.067974 & 0.0463 \\
\hline$\Delta(\boldsymbol{I N T}(-\mathbf{1}))$ & -0.130130 & 0.040597 & -3.205420 & 0.0029 \\
\hline$\Delta(\boldsymbol{I N T}(-\mathbf{2}))$ & 0.025951 & 0.034761 & 0.746558 & 0.4605 \\
\hline$\Delta(\boldsymbol{I N T}(-\mathbf{3}))$ & 0.051138 & 0.031685 & 1.613947 & 0.1158 \\
\hline$\Delta(\boldsymbol{I N F})$ & -0.001103 & 0.007628 & -0.144659 & 0.8858 \\
\hline$\Delta(\boldsymbol{E X \boldsymbol { R } )}$ & -0.721511 & 0.229864 & -3.138867 & 0.0035 \\
\hline$\Delta(\boldsymbol{T B})$ & 0.000142 & 0.015809 & 0.008995 & 0.9929 \\
\hline $\boldsymbol{E C T}(-\mathbf{1})$ & -0.084497 & 0.022089 & -3.825206 & 0.0005 \\
\hline
\end{tabular}

Source: The author's computation (2017).

The short-run estimates suggested that the first and second lags of output growth exerted a positive and significant impact on the current output growth in Nigeria. Thus, the short-run estimates of money supply, domestic credit, interest rate and inflation rate are also shown in Table 5. The error correction term indicates the speed of adjustment to restore equilibrium in the model. The value is negative at $1 \%$ significance level. Specifically, the lag of the error correction term (ECT) was found statistically significant at $1 \%$ level with the coefficient of -0.0845 . This 
indicates that $8.45 \%$ of the distortion in the short run is corrected in the first year of attainting equilibrium or output growth on the basis of the changes in the monetary policy variables and trade balance in Nigeria.

\subsection{Diagnostic Tests}

The estimated ARDL model is tested for heteroscedasticity, serial correlation, functional form misspecification, parameter stability and normality. The results from these tests are shown in Table 6.

Table 6. Diagnostic Tests of Selected ARDL Model

\begin{tabular}{|l|l|}
\hline \multicolumn{2}{|l|}{ Results } \\
\hline Serial Correlation: $2.5568[0.0926]$ & Normality Test: $1.1151[0.5724]$ \\
\hline Functional Form: $1.2416[0.2041]$ & Heteroskedasticity Test: $1.2574[0.3342]$ \\
\hline
\end{tabular}

Source: The author's computation (2017).

The estimated ARDL model revealed that the model passed the serial correlation, normal test, heteroscedasticity Ramsey RESET tests. The error terms were uncorrelated, normally distributed, the same variance and the model were not misspecified. Thus, they were satisfactory for the ARDL model.

\section{CONCLUSION}

This study has examined the impact of switching from direct to indirect monetary policy on industrial growth in Nigeria between 1960 and 2015. The analysis has been carried out using the Autoregressive Distributed Lag model developed by Perasan et al. (2001). The result of the cointegration test based on the bounds testing approach shows that the variables are mutually cointegrated, which suggests a long-run relationship between them in the model. The result of the shortrun dynamics shows that changes in the previous (one lagged) period of industrial growth, money supply, interest rate, exchange rate, domestic credit trade balance and inflation rate were negatively related to changes in industrial output growth. Based on the results obtained, the study recommends that policy makers should begin to think about the use of both a conventional and non-conventional monetary policy as an option for enhancing industrial output growth. The disequilibrium observed from the result can also be corrected by disbursing domestic credit to SMEs, new entrepreneurship, and emerging industrial investors in order to enhance a quick economic recovery.

\section{REFERENCES}

Adefeso, H. A. \& Mobolaji, H. I. (2010). The fiscal-monetary policy and economic growth in Nigeria: Further Empirical Evidence. Pakistan Journal of Social Sciences, 7(2), 137-142. https://doi.org/10.3923/pjssci.2010.137.142

Adeleke, I. A., Uboh, V. and Shobande, O. A. (2015). Monetary Policy Toward Inclusive Growth in Nigeria. Journal of Social Science, Nigeria Economics Society. University of Ibadan. 57(2), 80-114. 
Adeoye, W B. and Saibu, M. O. (2014). Monetary Policy Shocks and Exchange Rate Volatility in Nigeria, Asian Economic and financial Review, 4(4), 544-562.

Adeoye, W. B. and Shobande, O. A. (2016). Emergence of the New Monetary Policy Mandate and Macroeconomic Shock: A VAR Approach. Journal of Economic policy and Development. Department of Economics, University of Lagos, 1(1), 47-56.

Ajisafe, R. A., and Folorunso, B. A. (2002). The relative effectiveness of fiscal and monetary policy in macroeconomic management in Nigeria. Nigeria The African Economic and Business Review, 3(1).

Akujobi, L. E. (2012). Monetary Policy and Nigeria's Economic Development. African Research Review, 4(4), $153-161$.

Anwor, O. F. and Okorie, G. C. (2016). A reassessment of the Impact of Monetary Policy on Economic Growth: Study of Nigeria”, International Journal of Developing and Emerging Economies, European Centre for Research Training and Development UK 4(1), 82-90.

Bernhard, O. I. (2013). Monetary transmission mechanism in Nigeria: Causality test. Mediterranean Journal of Social Sciences, 4(13), 377-388.

Berument, H. and Dincer, I. N. (2008). Measuring the effects of monetary policy for Turkey. Bilkent University Journal of Economic Cooperation, 29(1), 83-110.

Bhuiyan, R. (2008). The Effects of Monetary Policy Shocks in a Small Open Economy: A Structural VAR Approach. Queen's University, Kingston, Ontario, Canada.

Chipote, P. and Makhetha- Kosi P. (2016). Impact of Monetary Policy on Economic Growth: A Case study of South Africa, Mediterranean Journal of Social Sciences, MCSER Publishing, Rome-Italy, 5(15).

Chuku, C. A. (2009). Measuring the effects of monetary policy innovations in Nigeria. African Journal of Accounting, Economics, Finance and Banking Research, 5(5), 141-153.

Dele, B. E. (2007). Monetary policy and economic performance of West African Monetary Zone Countries. University of Lagos, Nigeria.

Fasanya, I., Onakoya, A. \& Agboluaje, (2013). Does Monetary Policy Influences Economic Growth Michael in Nigeria? Asian Economic and Financial Review, 3(5), 635-646.

Khabo, V. S. (2002). The Impact of Monetary Policy of the Economic Growth of a Small and Open Economy: The case of South Africa, Department of Economics, University of Pretoria.

Baghebo, M. and Ebibai, T. S. (2014). Monetary policy and economic growth in Nigeria (1980-2011). Asia Economic and Financial Review, 4(1), 20-32.

Nouri, M. and Samimi, A. J. (2011). The Impact of Monetary Policy on Economic Growth in Iran. Middle-East Journal of Scientific Research, 9(6), 740-743.

Okoro, A. S. (2013). Impact of monetary policy on Nigeria Economic Growth. Prime Journal of Social Sciences, 2(2), 195-199.

Okwo, I. M. \& Eze, F. and Nwoha, C. (2012). Evaluation of monetary policy outcomes and its effect on price stability in Nigeria. Research Journal Finance and Accounting, 3(11), 37-47.

Olorunfemi, S. and Dotun, F. (2008). Stationarity analysis of the impact of monetary policy on economic performance in Nigeria. Pakistan Journal of Social Sciences 5(6), 562-566.

Omoka, P. C. \& Ugwuanyi, C. U. (2010). Money, price and output: A causality test for Nigeria. American Journal of Scientific Research, 8, 78-87.

Onyeiwu, C. (2012). Monetary policy and economic growth of Nigeria. Journal of Economic and Sustainable Development, 3(7), 62-70.

Owalabi, A. U. \& Adegbite, T. A. (2014). Impact of monetary policy on industrial growth in Nigeria. International Journal of Academic Research in Business and Social Sciences, 4(1), 18-31.

Pesaran, M. H. and Shin, Y. and Smith, R. J. (2001). Bounds Testing Approaches to the Analysis of Level Relationships. Journal of Applied Econometrics, 16, 289-326. https://doi.org/10.1002/jae.616

Rafiq, M. S. and Mallick, S. K. (2008). The effect of monetary policy on output in EMU3: A sign restriction approach. Journal of Macroeconomics, 30(4), 1756-1791. https://doi.org/10.1016/j.jmacro.2007.12.003

Shobande A.O and Oke, M. (2016). SMEs financing, diversification and long-term growth in Nigeria. Caleb Journal of Social and Management Sciences (CJSMS), 2(2).

Starr, M. A. (2005). Does money matter in the CIS? Effects of monetary policy on output and prices. Journal of Comparative Economics, 33(3), 441-461. https://doi.org/10.1016/j.jce.2005.05.006

Udude, C. (2014). Monetary Policy and Economic Growth in Nigeria (1981-2012). Journal of Policy and Development Studies, 9(1). https://doi.org/10.12816/0011194

Uhlig, H. (2004). What are the effects of monetary policy on output? Results from an agnostic identification procedure. Department of Economics Humboldt University Journal of Monetary Economics, 52(2), 381-419 https://doi.org/10.1016/j.jmoneco.2004.05.007

Umaru, A. \& Zubairu, A. A. (2012). Effect of inflation on the growth and development of the Nigerian economy (An empirical analysis). International Journal of Business and Social Science, 3(10), 183-193. 


\section{AUTHOR'S SHORT BIOGRAPHY}

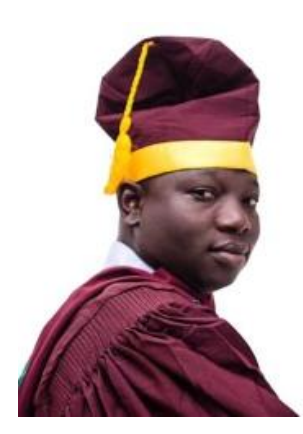

Shobande Olatunji Abdul is much-admired, award winning economist, writer and philosopher. A voice of the poor and malnourished, tirelessly engrossed in the problems of the society's poorest people, he has devised practical solutions on financial inclusion, fiscal and monetary policies in the Nigeria economy.

Currently, Shobande is a Ph.D. student at the Business School, University of Aberdeen, UK. Previously, Shobande obtained a First-Class degree in Economics from Caleb University and Distinction in MSc in Economics at the University of Lagos.

E-mail: o.shobande.19@abdn.ac.uk

ORCID iD: https://orcid.org/0000-0003-4528-1857 